\title{
Assessment of student's talent management in a corporate university
}

\author{
Hamidreza Ghomi ${ }^{a^{*}}$ and Hasan Ahmadi ${ }^{b}$
}

${ }^{a}$ Research institute of Technology Development, Tehran, Iran

${ }^{b}$ University of Mohaghegh Ardabili, Ardabil, Iran

\section{CHRON I CLE A B T RACT}

Article history:

Received: July 21, 2018

Received in revised format: July

21, 2018

Accepted: September 7, 2018

Available online:

September 7, 2018

Keywords:

Talent management

Talent development

Corporate university

\begin{abstract}
The purpose of this study was to evaluate the student's talent management of a corporate university in Iran by descriptive-analytic method. The statistical population of the study included all 2200 students of the university. Based on the estimated number at Morgan table, 202 respondents completed the survey instrument. The data collecting tool of the questionnaire was ascertained and its reliability was obtained 78 percent by Cronbach's alpha coefficient. Content validity of the tool was also verified by the experts. For data analysis, the binomial test and Structural Equation Modeling (SEM) were used. The results show that none of the components of talent management (deployment and employment, career progression path, practical learning, performance management, knowledge sharing, self-development, training, appreciation and encouragement) in the studied university was in desire conditions. Other findings of the study also show that among organizational factors, components of "organizational culture", "supervisor satisfaction", "organizational dynamics", "working environment conditions", "colleagues", "prestige and brand of the university" and "growth opportunity" were influential on the students' talent development. Also, the results of the data analysis show that among the components of job factors, the component of "person-job fitness" affects the development of students' talents.
\end{abstract}

\section{Introduction}

Talent management is seen as a critical factor in successful organizations. In fact, talent management is to carry out a series of integrated activities in order to ensure the attraction, maintenance, motivation and development of the skilled employees needed, now and in the future by the organization. In a public organization, key resources are the talent of people who work in the organization (Davies \& Davies, 2010). According to Sayers (2007), today the development and maintenance of talent is one of the biggest challenges faced by organizations, and organizations, both private and public, find it more difficult to develop and maintain their talents. It can be said that learning and developing skills is the most important capacity and ability of a talented organization (Davies \& Davies, 2010). Organizations must be able to identify people who are prone to their own, provide them with the necessary training and experience they need and maintain their valuable employees in the long-term (Sukanya, 2009). In a study of 40 companies including the whole world, it was shown that virtually, all of these companies acknowledge the lack of

* Corresponding author.

E-mail address: ghomi@jdsharif.ac.ir (H. Ghomi) 
sufficient talent to fill strategic positions in the organization, which significantly limits their ability to grow their businesses (Collings \& Mellahi, 2009). The success of today's organizations is increasingly associated with the attraction, maintenance and development of talented employees (Aguinis et al., 2012). Heuer (2003), believes that talent management is largely unknown in educational institutions. Despite the evidence of management practices that hold human capital in the business sector, most executives in higher education do not have a comprehensive talent management model as a strategic goal (Riccio, 2010). Although hiring well-informed and intelligent employees is important, their maintenance is more important (Hausknecht et al., 2009). Studies show that a significant percentage of companies and organizations are not successful in keeping their talents (Collings \& Mellahi, 2009; Fegley, 2006; Ready \& Conger, 2007). In addition, the talent management studies have paid attention to a lesser extent to the development and maintenance of talents, in spite of high level of its importance, and these two have taken a much smaller share of the researches. It can be said that at present, the main problem of organizations is that the demand for talent exceeds its supply, and organizations realize that in order to improve their competencies, they should think about identifying, developing and retaining qualified people (Garavan et al., 2012). Vural et al. (2012), argue that organizations are not successful in finding, developing, and maintaining their own employees and this reflects the lack of attention to talent management processes in the organization. According to McDonnell (2011), talent management is one of the most important factors in ensuring a sustainable organizational success. The talented individuals, as the source of a sustainable competitive advantage (Pornrat, 2010) play a very important role in achieving organizational goals and gaining and maintaining competitive advantage. Therefore, the development and maintenance of these people is of particular importance. It can be said that training in the development and maintenance of talents play important role (Stewart \& Brown, 2011; Mahapatro, 2010; Armstrong, 2006). Therefore, the results of this study could help to keep the talent at the studied university to avoid the costs that must be spent on the recruitment and training new forces. Therefore, according to the above, there are the following questions:

- What is the status of students' talent management at the corporate university of the study?

- To what extent do organizational factors affect the development of students' talents in the university?

- To what extent do job factors affect the development of students' talents in the university?

\section{Theoretical fundamentals and research background}

Within the dynamics of working life, organizations must adapt, develop, and achieve a high level of growth at the speed of changes. In order to maintain a profitable and sustainable competitive advantage, organizations need creative and innovative human resources (Altınöz et al., 2013). Scientific resources for defining the concept of talent management have led to various definitions that have been considered as a comprehensive and integrated process. Talent management is the development of strategies for hiring, keeping, and creating a talent pool. Before discussing talent management, the concept of "talent" should be explained.

The word "talent", which is used repeatedly in daily life, has become one of the really important sources of business. Talent is a concept that simultaneously considers skills, leadership, dominance, practicality, and better use of time. Another kind of definition is the ability of a person to do things in a given time frame easily and by using his creativity and to enable others to achieve success. As we can observe from Fig. 1, "talent" is defined as all concepts of dominance, ability, leadership, easiness, being exquisite, and time (Doğan \& Demiral, 2008). In fact, talent management is to employ the right person at the right place at the right time (Altınöz et al., 2013). 


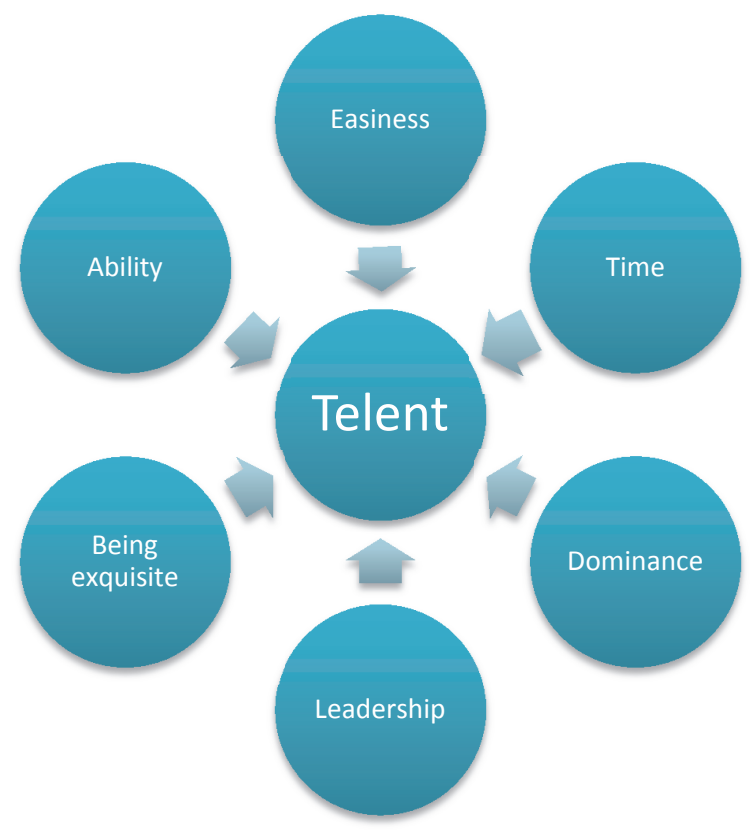

Fig. 1. Fundamental Features of Talent (Doğan \& Demiral, 2008)

\section{Overview of the reasons for the tendency to manage talent}

This section examines the views of some researchers and experts on talent management. Obviously, the views of these people make it even more important to address talent management, because in talent management, human resources become an element of the facilitator and the business partner of the organization versus the administrative role in other perspectives. Wellins et al. (2008), find success in a highly competitive environment and a highly complex global economy as one of the reasons for tendency to manage talent.

Pitt-Catsouphes et al. (2009), considered two fundamental changes in the business environment to be one of the reasons for tendency toward talent management. These researchers believe that economic pressure on one hand and the demographic pressure of the workforce on the other hand have led to these widespread changes. Economic pressures have led to the use of the least talented staff and demographic pressures have become more apparent with the advent of skilled labor aging. Ashton and Morton (2005) believe that new cycles in business growth require talented workforce. In the view of these researchers, the change factor in the demographic trend of the workforce has also led to a dramatic drop in talent pool and a lack of skilled workforce. Most importantly, today's complex economy is due to the fact that it emphasizes the existence of talent management. Another point is the emergence of new organizations that emphasize the existence of the talented individuals in the ultra-bureaucratic world. Also, the emphasis on leadership in globalization has added to the importance of talent management. Ashton and Morton (2005), know the role of talent management so valuable that it is considered to be a factor in promoting the organization's effectiveness. They argue that talent management, through the integration of human resources strategies with business planning, can enhance organizational performance, individuals' ability, implementation of strategies and operational excellence, and add to organizational effectiveness. Garrow and Hirsh (2008), have cited several reasons for tendency toward talent management. They believe that talent management is the best way to develop human resources in the future. Beechler and Woodward (2009), consider the demographic and economic trends of the world, the ever-increasing movement of individuals and organizations, the fundamental changes in the business environment, skills and culture, and the growing levels of work force diversity in the tendency to manage talent. Talent management factors in other studies are presented in Table 1. 
Table 1

Talent management factors in other studies

Factors

Author Research objective

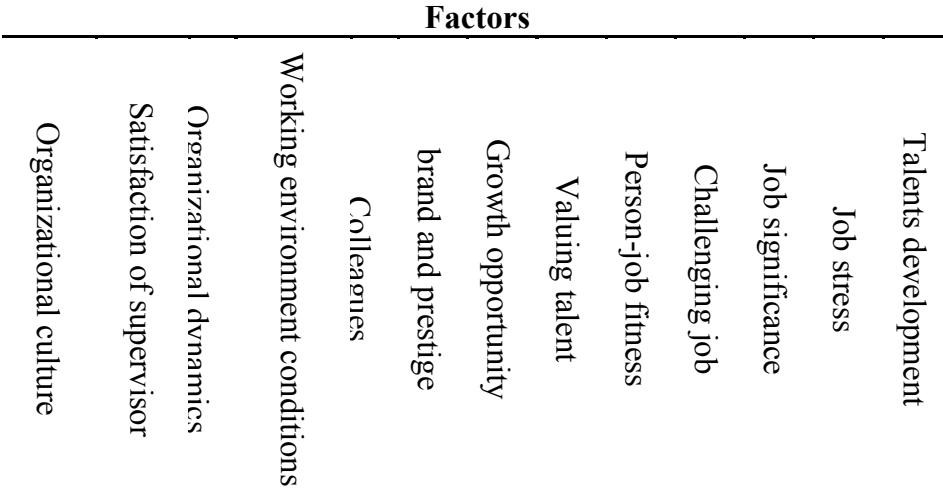

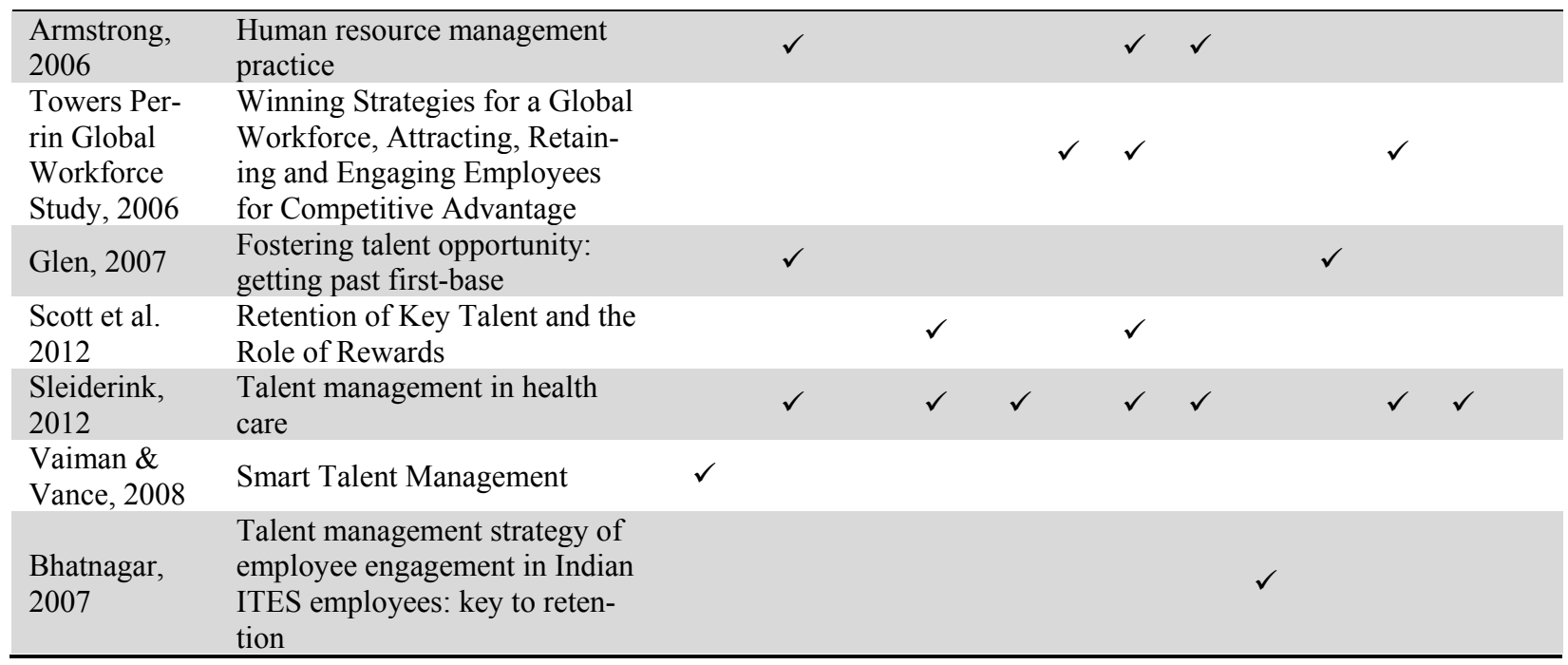

\section{Research background}

Megri (2014) concluded that talent management system had a significant effect on employee performance. Altınöz et al. (2013) performed a survey on the effects of talent management on organizational performance and concluded that talent management had a significant effect on organizational trust, organizational effectiveness and organizational performance. Vural et al. (2012), in their research on the effect of using talent management with a performance evaluation system on employee commitment, which conducted among 126 senior executives, concluded that talent management as a means of integrating human resources and performance systems had a positive impact on employee commitment. Swapna and Raja (2012), also reviewed the status of talent management in the service sector and compared it to the two sectors of education and health. The results indicated that there was no significant difference between the responses of the employees of the mentioned sections in understanding the importance of talent management and its impact on business transformation. Also, the results of their studies show that employees agreed with all the variables related to talent management. They feel that talent management led to higher financial gains and influenced business practices. The basic research model, based on the literature review, is presented in Fig 2. 


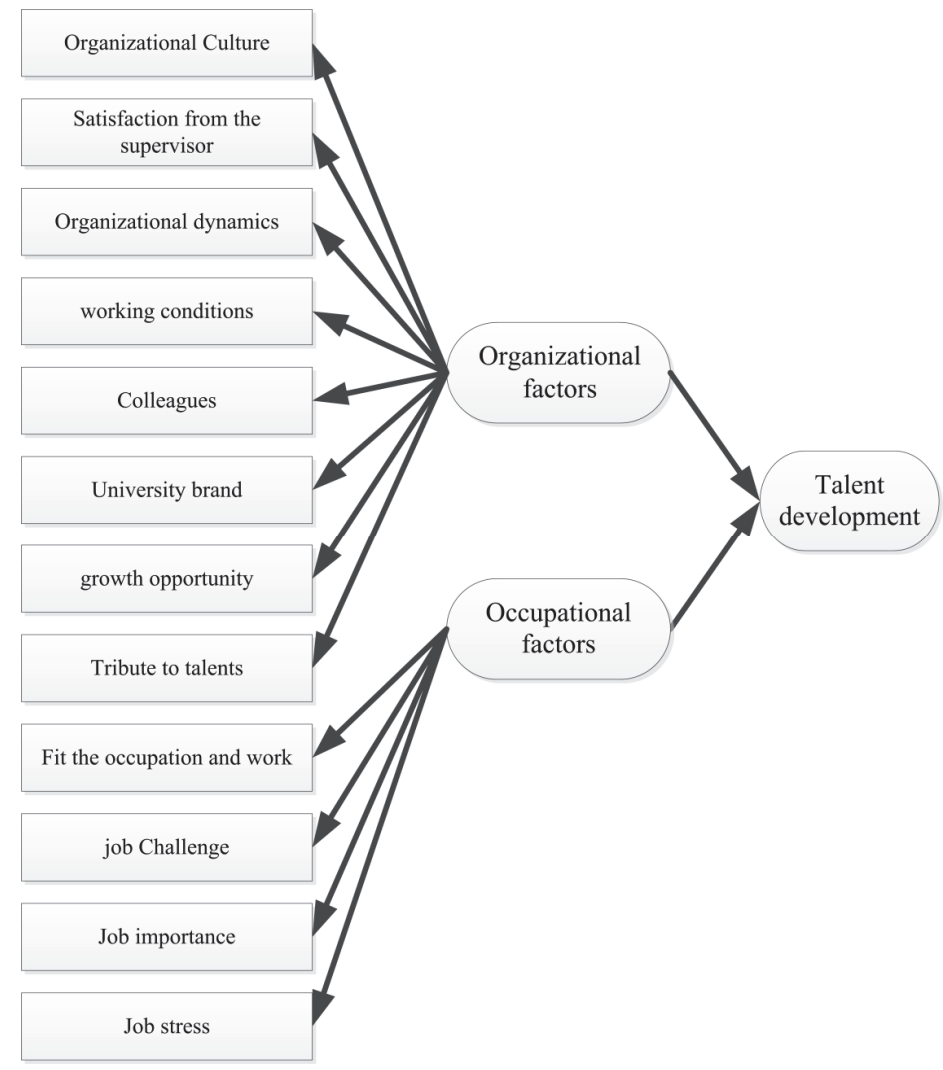

Fig. 2. The basic research model

\section{Research methodology}

Since the present research aims to determine the status of talent management among students of a corporate university in Iran, and also is formed based on the fact that the evaluation and determination of the status of talent management in the organization studied leads to the presentation of results that will affect the performance of the university; therefore, based on the categorization of research based on the purpose, this is an applied research. The purpose of an applied research is the development of applied knowledge in a particular context. In other words, applied research is directed towards the practical application of knowledge. Also, by considering that the present research will describe the conditions, the method of data collection is descriptive (non-experimental) and correlational by using SEM method. SPSS and Smart-PLS software were used for quantitative analysis of data. Descriptive research is a research that describes the actual and regular characterization of a particular situation or subject. The statistical population of this study included the total number of 2200 students of a corporate university in Iran, which was estimated 242 people by cluster sampling method based on Morgan's table. The estimated number at Morgan table, 202 respondents completed the survey instrument. Regarding the rate of people not responding was less than 20 percent, this number was acceptable for the conclusion of statistical data. The tool in this research is a researcher-made questionnaire including 23 questions, which contains the elements of deployment and employment, career progression path, practical learning, performance management, knowledge sharing, self-development, training, appreciation and encouragement. Two criteria of composite reliability and Cronbach's alpha were applied in order to examine the reliability. The rate of these two criteria must be higher than 0.70 . As shown in Table 2, in the composite reliability (P DelvinGoldstein) and Cronbach's alpha, all variables related to talent development Index are higher than 0.70, so the reliability of the measurement tools is confirmed. Content validity of the questionnaire has been approved by the experts. 
Table 2

Composite reliability and Cronbach's alpha values for measuring talent development index

\begin{tabular}{ccc}
\hline Index & Composite Reliability & Cronbach's Alpha \\
\hline Appreciation and encouragement & 0.883 & 0.823 \\
Career progress path & 0.839 & 0.716 \\
Self - development & 0.84 & 0.713 \\
Deployment and employment & 0.939 & 0.913 \\
Training & 0.858 & 0.77 \\
Practical learning & 0.898 & 0.774 \\
Performance management & 0.82 & 0.77 \\
Sharing knowledge & 0.825 & 0.787 \\
\hline
\end{tabular}

\section{Research findings}

\subsection{Descriptive binomial test}

In order to analyze the research data, descriptive binomial test and SEM have been used.

-How is the talent management situation among the corporate university students studied?

The first hypothesis of the research can be stated as follows:

$H_{0}$ : The status of $i$ th component of talent development among the students of the studied university is not in proper condition.

$H_{1}$ : The status of $i$ th component of talent development among the students of the studied university is in proper condition.

To investigate the first hypothesis and determine the status of talent management among the students of the studied university, binomial test has been used. The results of this test are presented in Table 3 . The researchers can divide the variables into two categories based on the test results:

- Variables that are at the optimal level: whose meaningful level is less than 0.05 , and the frequency of individuals with higher average scores (3) is higher and displayed with the $\mathrm{H}$ symbol.

- Variables that are not at the optimal level: whose calculated meaningful level is less than the value of 0.05 and the frequency of individuals with an average score higher than (3) is lower or the calculated meaningful level is higher than 0.05 and is displayed with $\mathrm{L}$ symbol.

Table 3

Binomial test results to examine the status of talent management components

\begin{tabular}{|c|c|c|c|c|c|c|}
\hline Variable & Group & Frequency & $\begin{array}{l}\text { Frequency } \\
\text { percentage }\end{array}$ & Test ratio & $\begin{array}{c}\text { Significance } \\
\text { level }\end{array}$ & $\begin{array}{c}\text { Test re- } \\
\text { sult }\end{array}$ \\
\hline Deployment \& employment & $<=3$ & 112 & $55 \%$ & 0.5 & 0.139 & \multirow[t]{2}{*}{$\mathrm{L}$} \\
\hline \multirow{3}{*}{ Career progress path } & $>3$ & 90 & $45 \%$ & & & \\
\hline & $<=3$ & 143 & $71 \%$ & 0.5 & 0.001 & \multirow{2}{*}{$\mathrm{L}$} \\
\hline & $>3$ & 59 & $29 \%$ & & & \\
\hline \multirow{2}{*}{ Practical learning } & $<=3$ & 108 & $53 \%$ & 0.5 & 0.36 & \multirow{2}{*}{$\mathrm{L}$} \\
\hline & $>3$ & 94 & $47 \%$ & & & \\
\hline \multirow{2}{*}{ Performance management } & $<=3$ & 113 & $56 \%$ & 0.5 & 0.105 & \multirow{2}{*}{$\mathrm{L}$} \\
\hline & $>3$ & 89 & $44 \%$ & & & \\
\hline \multirow{2}{*}{ Sharing knowledge } & $<=3$ & 150 & $74 \%$ & 0.5 & 0.001 & \multirow{2}{*}{$\mathrm{L}$} \\
\hline & $>3$ & 52 & $26 \%$ & & & \\
\hline \multirow{2}{*}{ Self-development } & $<=3$ & 142 & $70 \%$ & 0.5 & 0.001 & \multirow{2}{*}{$\mathrm{L}$} \\
\hline & $>3$ & 60 & $30 \%$ & & & \\
\hline \multirow{2}{*}{ Training } & $<=3$ & 106 & $52 \%$ & 0.5 & 0.527 & \multirow{2}{*}{$\mathrm{L}$} \\
\hline & $>3$ & 96 & $48 \%$ & & & \\
\hline \multirow{2}{*}{ Appreciation \& encouragement } & $<=3$ & 117 & $58 \%$ & 0.5 & 0.029 & \multirow{2}{*}{$\mathrm{L}$} \\
\hline & $>3$ & 85 & $42 \%$ & & & \\
\hline Talents management & $\begin{array}{c}<=3 \\
>3\end{array}$ & $\begin{array}{c}113 \\
89\end{array}$ & $\begin{array}{l}56 \% \\
44 \%\end{array}$ & 0.5 & 0.105 & $\mathrm{~L}$ \\
\hline
\end{tabular}


According to Table 3, from the respondents' point of view, none of the 8 components of talent management and the overall indicator of talent management in the corporate university studied is in a proper position.

\subsection{Structural model of research}

After reviewing the conceptual model, we examine the conceptual model of the research. The graphical output of the research model is shown in Fig. 3.

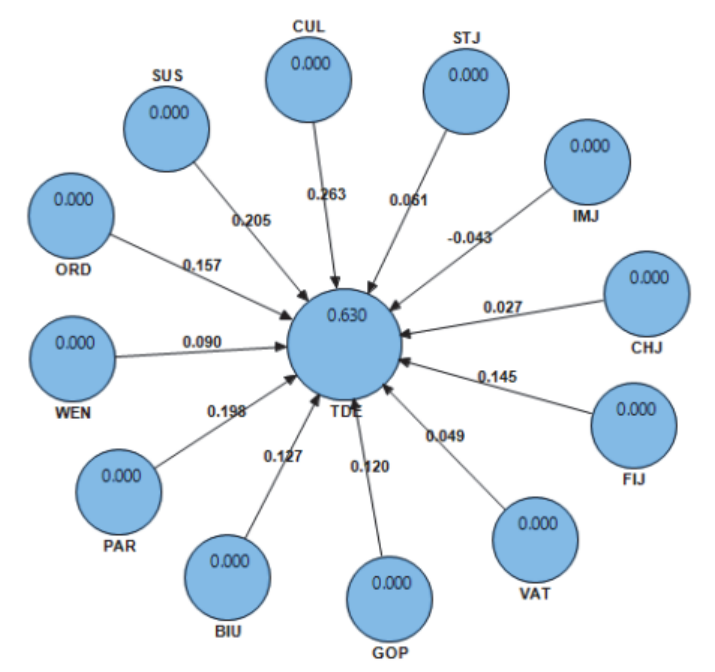

Fig. 3. Standard path coefficients of the conceptual model of the research

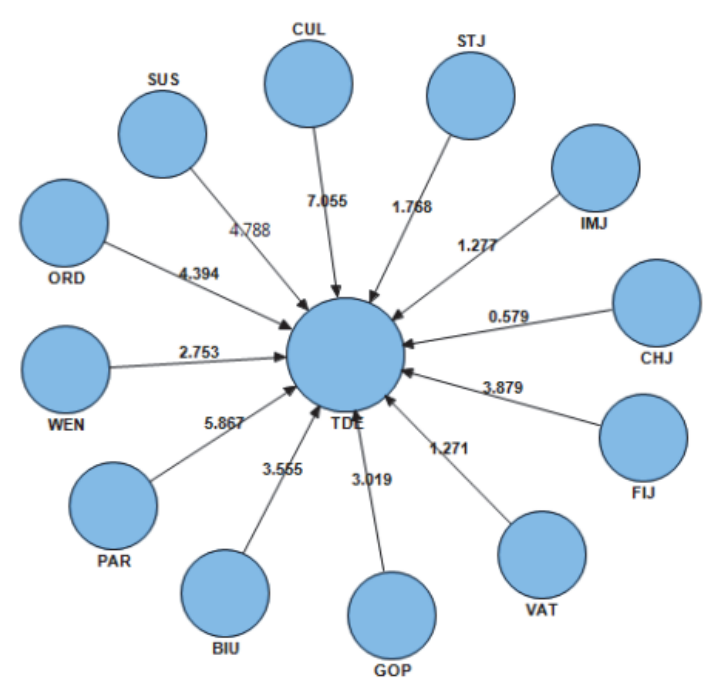

Fig. 4. T-Student test results for examining the significance of the path coefficients

The numbers written on the paths represent the path coefficients. To test the significance of the path coefficients, the t-student test values have been calculated by using bootstrapping method. If the t-student's test values are greater than 1.96, then the path coefficient has significance level 0.05 .

\subsection{Review the adequacy of the model}

\subsubsection{R-squared benchmark}

The R-squared benchmark refers to the inbred (dependent) variables of the model. R-squared is a benchmark that shows the effect of an inbred variable on an inbred variable, and three values $0.19,0.33$ and 0.67 are considered as the benchmark values for weak, moderate and strong values, respectively. According to Table 4, the value for the inbred structure of talent development is calculated 0.630, which, according to the benchmark value, confirms the suitability of fitting the structural model (Chin, 1994).

\subsubsection{Q-squared benchmark}

Q-squared benchmark specifies the predictive power of the model, and if its value for an inbred structure has three values of $0.02,0.15$, and 0.35 , then it indicates the weak, moderate and strong predictive power of the structure, respectively. $\mathrm{Q}^{2}$ value for the inbred structure of the talents development is calculated 0.281 , indicating the predictive power of the model for the inbred structures of the research and confirms suitable fitting of the structural model (Chin, 1994). 


\subsubsection{GOF benchmark}

Another benchmark introduced for fitting by Tenenhaus et al. (2005). The general fitting benchmark is Goodness-of-fit (GOF) which is calculated by calculating the geometric average of the intersection average and is calculated as follows.

$$
\text { GOF }=\sqrt{\overline{\text { communality }} \times \overline{R^{2}}}
$$

This index acts like Lisrel fitting model and is between zero and one, and values which are close to one represent the suitable quality of the model. It should be noted, however, that this benchmark, like the chisquared benchmark in Lisrel models, does not examine the fitting rate of the theoretical model with the collected data; It examines the predictive power of the overall model and whether the tested model has been successful in predicting the inbred variables or not.

\section{Table 4}

Communality and R-squared rate of variables of research

\begin{tabular}{lcc}
\hline Variable & Communality & $\mathbf{R}^{\mathbf{2}}$ \\
\hline Organizational culture & 0.838 & -- \\
Satisfaction of supervisor & 0.779 & -- \\
Organizational dynamics & 0.703 & -- \\
Working environment conditions & 0.869 & -- \\
Colleagues & 0.844 & -- \\
University brand and prestige & 0.836 & -- \\
Growth opportunity & 0.794 & -- \\
Valuing talent & 0.786 & -- \\
Person-job fitness & 0.668 & -- \\
Challenging job & 0.700 & -- \\
Job significance & 0.758 & -- \\
Tob stress & 0.836 & -- \\
Average & 0.832 & $\mathbf{0 . 6 3 0}$ \\
\hline
\end{tabular}

$$
G O F=\sqrt{\overline{\text { communality }} \times \overline{R^{2}}}=\sqrt{0.788 \times 0.630}=0.705
$$

GOF value for the research model according to Table 4 has been calculated as 0.705 , which indicates the average power of the model in predicting the inbred latent variable of the model.

The first hypothesis: How do organizational factors affect the development of talents among university students? In order to examine the first hypothesis and the significance test of the path coefficients between variables, the software output has been used. The path coefficients and the results related to their significance are given in the following table.

\section{Table 5}

\begin{tabular}{|c|c|c|c|c|c|}
\hline \multirow{2}{*}{ Row } & \multicolumn{2}{|l|}{ Path } & \multirow{2}{*}{$\begin{array}{l}\text { Path coefficient } \\
\text { ( } \beta)\end{array}$} & \multirow{2}{*}{$\begin{array}{l}\text { Significant } \\
\text { number } \\
\text { (t-value) }\end{array}$} & \multirow{2}{*}{ Test result } \\
\hline & From variable & To variable & & & \\
\hline 1 & Organizational culture & \multirow{8}{*}{$\begin{array}{c}\text { Talents } \\
\text { development }\end{array}$} & 0.263 & 7.055 & Confirmed \\
\hline 2 & Satisfaction of supervisor & & 0.205 & 4.788 & Confirmed \\
\hline 3 & Organizational dynamics & & 0.157 & 4.394 & Confirmed \\
\hline 4 & Working environment conditions & & 0.09 & 2.753 & Confirmed \\
\hline 5 & Colleagues & & 0.198 & 5.867 & Confirmed \\
\hline 6 & University brand and prestige & & 0.127 & 3.555 & Confirmed \\
\hline 7 & Growth opportunity & & 0.120 & 3.019 & Confirmed \\
\hline 8 & Valuing talent & & 0.049 & 1.271 & Rejected \\
\hline
\end{tabular}

Results of the structural model evaluation for the first hypothesis 
According to Table 5, significance statistic between the variable of "talents development" and "organizational culture", "Satisfaction of supervisor", "Organizational dynamics", "Working environment conditions", "Colleagues", "University brand and prestige", "Growth opportunity" are greater than (1.96), indicating that the relationship between these components and the development of talents is significant at the level of confidence $(95 \%)$. Also, the positive path coefficients indicate a positive effect of 7 factors on the development of talents. But the significance statistics between the "talents development" and "valuing talent" is lesser than 1.96, which indicates that valuing talents has no significant effect on talent management.

The second hypothesis: What is the effect of job factors on the development of talent among the university students?

In order to examine the second hypothesis and the significance test of the path coefficients between variables, the software output has been used. The path coefficients and their significant results are given in the following table.

Table 6

The results of the structural model evaluation for the second hypothesis

\begin{tabular}{|c|c|c|c|c|c|}
\hline \multirow{2}{*}{ Row } & \multicolumn{2}{|c|}{ Path } & \multirow{2}{*}{$\begin{array}{c}\text { Path coefficient } \\
\text { ( } \beta)\end{array}$} & \multirow{2}{*}{$\begin{array}{c}\text { Significant } \\
\text { number } \\
\text { (t-value) }\end{array}$} & \multirow{2}{*}{ Test result } \\
\hline & From variable & To variable & & & \\
\hline 1 & Person-job-fitness & \multirow{4}{*}{$\begin{array}{c}\text { Talents } \\
\text { development }\end{array}$} & 0.145 & 3.879 & Confirmed \\
\hline 2 & Challenging the job & & 0.027 & 0.579 & Rejected \\
\hline 3 & Job significance & & -0.043 & 1.277 & Rejected \\
\hline 4 & Job stress & & 0.61 & 1.768 & Rejected \\
\hline
\end{tabular}

According to Table 6, a significance statistics between the variables of the "talents development" and the "person-job-fitness" is 3.879 and greater than (1.96), indicating that the relationship between "personjob-fitness" and the "talents development" at the level of confidence $(95 \%)$ is significant. Also, the path coefficient between these two variables is equal to 0.41 , which indicates the positive impact of "personjob-fitness" on the "talent development". But a significance statistic between the "talents development" and the "Challenging job", "importance of the job", and "job stress" is lesser than 1.96, which indicates that these three variables do not effect on the talent management.

\section{Discussion and conclusion}

The purpose of this research was to assess the students' talent management of a corporate university in Iran. The results of this study have shown that none of the 8 components of talent management (deployment and employment, career progression, practical learning, performance management, knowledge sharing, self-development, training, appreciation and encouragement), and general index of talent management in the studied corporate university was in proper condition.

The results of the second hypothesis indicate that among the organizational factors, the components of organizational culture, satisfaction of supervisor, organizational dynamics, working environment conditions, colleagues, prestige and brand of the university, growth opportunity are effective on the development of students' talents. Also, the results of the third hypothesis indicate that among the components of the job factors, only the person-job-fit affects the development of students' talents. In the explanation of the research findings, it can be said that the results of the present study are in line with the findings of Mwangi (2009), Kimani and Waithaka (2013), Kotzé \& Roodt (2005), Vaiman \& Vance (2008), Natalie et al. (2011), Cave et al. (2013), Fukofuka (2014) and Sleiderink (2012).

Also, Sleiderink (2012), divided the factors influencing talents maintenance into two categories of internal factors and external factors. The findings of this study showed that the most important internal factors 
affecting the talents maintenance include job independence, development opportunities, job satisfaction, challenging work, and appreciation. Also, the results of the research showed that the most important external factors affecting the maintenance of talents include relationships with colleagues, working conditions, job security, promotion opportunities and wages. Kimani and Waithaka (2013) found that organizational culture, reward system, job development, and work environment were among the most important factors influencing the implementation of talent management in the organization and could predict successful talent management in the organization.

In explaining these findings, it should be noted that the university should strive to provide growth and prosperity opportunities for the talents, so that besides working in the organization, they grow their professional skills. In other words, the organization provides these people the study and research, self-development, and reconstruction opportunities, which can be in the forms of participating the talents in university problems, attending them in upper hands meetings, and exposing them to learningy.

\section{Acknowledgement}

The authors would like to thank the anonymous referees for constructive comments on earlier version of this paper.

\section{References}

Aguinis, H., Gottfredson, R. K., \& Joo, H. (2012). Using performance management to win the talent war. Business Horizons, 55(6), 609-616.

Altıöz, M., Çakıroğlu, D., \& Çöp, S. (2013). Effects of talent management on organizational trust: A field Study. Procedia-Social and Behavioral Sciences, 99(2013), 843-851.

Armstrong, M. (2006). A Handbook of Human Resource Management Practice. $10^{\text {th }}$ Edition, London: Kogan Page Publishing.

Armstrong, M. (2006). Human resource management practice. $10^{\text {th }}$ edition. Printed and bound in Great Britain by Cambridge University Press.

Ashton, C., \& Morton, L. (2005). Managing talent for competitive advantage: Taking a systemic approach to talent management. Strategic HR review, 4(5), 28-31.

Beechler, S. \& Woodward, I. C. (2009). The global "war for talent”. Journal of International Management. 15(3), 273-285.

Bhatnagar, J. (2007). Talent management strategy of employee engagement in Indian ITES employees: key to retention. Employee relations, 29(6), 640-663.

Cave, A. H., Chung, W-H. \& Choi, S. (2013). Determining the factors affecting retention of employees in Taiwanese electronics firms - General vs. Repatriated Employees. International Journal of Academic Research in Business and Social Sciences, 3(1), 100-118.

Chin, W. W. (1994). PLS-Graph user's guide' version 3.0. Houston, TX: Soft Modelling.

Collings, D. G., \& Mellahi, K. (2009). Strategic talent management: A review and research agenda. Human Resource Management Review, 19(4), 304-313.

Davies, B., \& Davies, B. J. (2010). Talent management in academies. International Journal of Educational Management, 24(5), 418-426.

Doğan, S. \& Demiral, Ö. (2008). İnsan kaynakları yönetiminde çalışanların kendilerine doğru yolculuk yöntemi: yetenek yönetimi (Journey towards oneself as a strategy in human resources management: talent management), Çukurova University Journal of Social Sciences Institute, 17(3), 145-166.

Fegley, S. (2006). Talent Management Survey Report, SHRM Research, Alexandria, VA.

Fukofuka, S. (2014). Factors that predict employee retention in profit and not-for- profit organizations. Global Journal of Human Resource Management. 2(4). 1-8.

Garavan, T. N., Carbery, R., \& Rock, A. (2012). Mapping talent development: definition, scope and architecture. European Journal of Training and Development, 36(1), 5-24. 
Garrow, V. \& Hirsh, W. (2008). Talent Management: Issues of Focus and Fit. Public Personnel Management, 37(4), 389-402.

Glen, C. (2007). Fostering talent opportunity: getting past first-base. Strategic Direction, 23(10), 3-5.

Hausknecht, J.P., Howard, M.J., Rodda, J. (2009). Targeted employee retention: Performance and Job related differences in reported reasons for staying. Human resources Management, 48(2), 269-288.

Heuer, J. J. (2003). Succession planning for key administrators at Ivy-Plus universities. PhD Dissertation, USA: University of Pennsylvania.

Kotzé, K. \& Roodt, G. (2005). Factors that affect the retention of managerial and specialist staff: an exploratory study of an employee commitment model. SA Journal of Human Resource Management, $3(2), 48-55$.

Mahapatro, B. B. (2010). Human resource management. Published by New Age International Publishers.

McDonnell, A. (2011). Still Fighting the "War for Talent"? Bridging the Science versus Practice Gap. Journal of Business and Psychology, 26(2), 169-173

Megri, Z. (2014). The impact of talent management system on the enterprise performance: a study on a sample of workers in national company of juice and canned-food unit MANAA (Batna). Arab Economic and Business Journal, 9(2), 156-165.

Michaels, E., Handfield-Jones, H., \& Axelrod, B. (2001). The War for Talent. Harvard Business Press.

Mwangi, W. (2009). Factors affecting talent management at nation media group. Master Dissertation. Kenya: Strathmore University.

Natalie, G., Eva, K., Filip, D., \& Herman, B. (2011). Influence of learning and working climate on the retention of talented employees. Journal of Workplace Learning, 23(1), 35-55.

Pitt-Catsouphes, M., Sweet, S., Lynch, K. \& Whalley, E. (2009). The Pressures of Talent Management.The Sloan Center on Aging \& Work. USA: Boston University.

Pornrat S. (2010). The determinants of talent retention in the Thai public sector. PhD Dissertation. School of public administration, national institute of development administration.

Ready, D. A., \& Conger, J. A. (2007). Make your company a talent factory. Harvard business review, $85(6), 68$.

Riccio, S. (2010). Talent Management in Higher Education: Developing Emerging Leaders with in the Adminstration at Private Colleges and Universities, PhD Dissertation. Lincoln: University of Nebraska.

Sayers, R. (2007). The right staff from X to Y: Generational change and professional development in future academic libraries. Library Management, 28(8/9), 474-487.

Scott, D., McMullen, t. \& Royal, M. (2012). Retention of Key Talent and the Role of Rewards. World at Work, www.worldatwork.org

Sleiderink, D.E.M. (2012). Talent management in health care: Identifying and retaining talent at Medisch Spectrum Twente. PhD Dissertation. Netherlands: University of Twente.

Kimani, S. M., \& Waithaka, S. M. (2013). Factors Affecting Implimentation of Talent Management in State Corporations: A Case Study of Kenya Broadcasting Corporation. International Journal of Business and Social Research, 3(4), 42-49.

Stewart, G. L. \& Brown, K. G. (2011). Human Resource Management: Linking Strategy to Practice. Second edition. John Wiley \& Sons, Inc.

Sukanya, M. (2009). Talent management strategies and challenges in the competitive era: a study of select software \& BPO companies in India. PhD Dissertation, India: Jawaharlal Nehru Technological University.

Swapna. R., \& Raja K. G. (2012). Business Transformation Management- The Role of Talent management with Special Reference to Service Sectors. Advances In Management, 5(2), 61-64.

Tenenhaus, M.; Vinizi, V, E. Cgatelin, Y. M.; Lauro, C. (2005). PLS path modeling. Computational Statistics and Data Analysis, 48(1), 159-205.

Towers Perrin Global Workforce Study (2006). Winning Strategies for a Global Workforce, Attracting, Retaining and Engaging Employees for Competitive Advantage. Retrieved December 4, 2015, from http://www.multiculturaladvantage.com/recruit/diversity/global-diversity/Towers-Perrin-GlobalWorkforce-Study.asp 
Vaiman, V., \& Vance, C. M. (2008). Smart Talent Management. Cheltenham: Edward Elgar Publishing. Vural, Y., Vardarlier,P., Aykir, A. (2012). The effects of using talent management with performance evaluation system over employee commitment. Social and behavioral sciences, 58(2012), 340-349.

Wellins, R.S., Smith, A.B. \& Erker, S. (2008). Nine Best Practices for Effective Talent Management. DDI, Inc. White Papers.

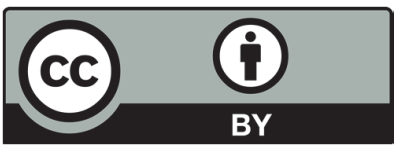

(C) 2018 by the authors; licensee Growing Science, Canada. This is an open access article distributed under the terms and conditions of the Creative Commons Attribution (CCBY) license (http://creativecommons.org/licenses/by/4.0/). 